\title{
Pollination of two species of Vellozia (Velloziaceae) from high-altitude quartzitic grasslands, Brazil
}

\author{
Claudia Maria Jacobi ${ }^{1,3}$ and Mário César Laboissiérè del Sarto $^{2}$
}

\author{
Received: May 12, 2006. Accepted: October 2, 2006
}

\begin{abstract}
RESUMO - (Polinização de duas espécies de Vellozia (Velloziaceae) de campos quartzíticos de altitude, Brasil). Foram pesquisados os polinizadores e o sistema reprodutivo de duas espécies de Vellozia (Velloziaceae) de campos rupestres quartzíticos do sudeste do Brasil. Vellozia leptopetala é arborescente e cresce exclusivamente sobre afloramentos rochosos, V. epidendroides é de porte herbáceo e espalhase sobre solo pedregoso. Ambas têm flores hermafroditas e solitárias, e floradas curtas em massa. Avaliou-se o nível de auto-compatibilidade e a necessidade de polinizadores, em 50 plantas de cada espécie e 20-60 flores por tratamento: polinização manual cruzada e autopolinização, polinização espontânea, agamospermia e controle. O comportamento dos visitantes florais nas flores e nas plantas foi registrado. As espécies são auto-incompatíveis, mas produzem poucas sementes autogâmicas. A razão pólen-óvulo sugere xenogamia facultativa em ambas. Foram visitadas principalmente por abelhas, das quais as mais importantes polinizadoras foram duas cortadeiras (Megachile spp.). Vellozia leptopetala também foi polinizada por uma espécie de beija-flor territorial. A produção de sementes em frutos de polinização cruzada sugere que limitação por pólen é a causa principal da baixa produção natural de sementes. Isto foi atribuído ao efeito combinado de cinco mecanismos: autopolinização prévia à antese, elevada geitonogamia resultante de arranjo floral, número reduzido de visitas por flor pelo mesmo motivo, pilhagem de pólen por diversas espécies de insetos e, em $V$. leptopetala, deposição de pólen heteroespecífico em conseqüência da promiscuidade dos beija-flores.
\end{abstract}

Palavras-chave: limitação polínica, geitonogamia, campos rupestres, auto-incompatibilidade, Serra do Cipó

\begin{abstract}
Pollination of two species of Vellozia (Velloziaceae) from high-altitude quartzitic grasslands, Brazil). The pollinators and breeding system of two species of Vellozia (Velloziaceae) from high-altitude quartzitic grasslands in SE Brazil were studied. Vellozia leptopetala is shrubby and grows solely on rocky outcrops, V. epidendroides is herbaceous and grows on stony soils. Both bear solitary, hermaphrodite flowers, and have massive, short-lasting annual blooms. We evaluated the level of self-compatibility and need for pollinators of 50 plants of each species and 20-60 flowers per treatment: hand self- and cross-pollination, spontaneous pollination, agamospermy and control. The behavior of floral visitors on flowers and within plants was recorded. Both species are mostly selfincompatible, but produce a small number of seeds by self-fertilization. The pollen-ovule ratio suggests facultative xenogamy. They were visited primarily by bees, of which the most important pollinators were two leaf-cutting bees (Megachile spp.). Vellozia leptopetala was also pollinated by a territorial hummingbird. Low natural seed production compared to cross-pollination seed numbers suggests that pollen limitation is the main cause of low seed set. This was attributed to the combined effect of five mechanisms: selfing prior to anthesis, enhanced geitonogamy as a result of large floral displays, low number of visits per flower for the same reason, pollen theft by many insect species, and, in $V$. leptopetala, delivery of mixed pollen loads on the stigma as a consequence of hummingbird promiscuity.
\end{abstract}

Key words: pollen limitation, geitonogamy, rocky grasslands, self-incompatibility, Serra do Cipó

\section{Introduction}

Lack of suitable pollination, together with resource limitation, have been two important factors traditionally held responsible for incomplete fruit and seed set, particularly self-progeny (Queller 1985; Haig \& Westoby 1988; Guitián \& Navarro 1996; Collevatti et al. 1997; Lindell 1998; Niesenbaum 1999). The causes and consequences of pollen limitation in particular have been the object of much attention in recent years (Ashman et al. 2004).

Reduced seed set by pollen limitation is often the result of combined quantitative and qualitative mechanisms. Quantitative pollen limitation has been related to lack of suitable pollinators, in association with a temporary lack of visits because of climate, habitat alterations or heterogeneity (Schiller et al. 2000; Moody-Weiss \& Heywood 2001; Montgomery et al.

\footnotetext{
1 Universidade Federal de Minas Gerais, Departamento de Biologia Geral, ICB, Av. Antônio Carlos 6627, 31270-901 Belo Horizonte, MG, Brazil

2 Universidade Federal de Viçosa,Departamento de Biologia Animal, Av. P.H. Rolfs, 36570-000 Viçosa, MG, Brazil

3 Corresponding author: jacobi@icb.ufmg.br
} 
2003), competition with other floral resources (but see Feldman et al. 2004), or initial colonization of a new area (Larson et al. 2002). Qualitative pollen limitation is closely related to the plant breeding system and derives from visits that do not necessarily bring the correct kind of pollen to the stigma. It has been claimed to result from either increased self-pollination (de Jong et al. 1993, and references therein; Shibayama \& Kadono 2003) or heterospecific pollen transfer (Fishman \& Wyatt 1999; Brown \& Mitchell 2001; Yang et al. 2005), and floral display is pointed out as a key factor affecting these processes. A poor floral display will be overlooked by visitors, resulting in small quantities of pollen deposited and removed. On the other hand, a large floral display attracts more pollinators to the plant but these tend to visit more flowers on each plant, increasing the rate of self-pollen transfer within the plant, albeit less than proportionally (Robertson 1992; Robertson \& MacNair 1995; Schiller et al. 2000; Ohashi \& Yahara 2002). Although exceptions have been reported (Ohara \& Higashi 1994), a long sequence of visits to flowers in a plant is usually detrimental for seed set (e.g. Iwasa et al. 1995), both in self-incompatible species, resulting in little or no seed production, and self-compatible species, which usually manifest some degree of inbreeding depression. Evaluating the causes and effects of enhanced selfpollination is particularly important in self-incompatible, massive blooming species, as is the case of several Velloziaceae.

Velloziaceae is a small family of approximately 250 species of fibrous shrubby plants (Mello-Silva 2005). Its members grow mainly in edaphically dry localities of South America, Africa and Madagascar. Individuals are typical elements of tropical inselbergs (rock hilltops), and bear resistance characteristics such as quiescence (Owoseye \& Sanford 1972), droughtenduring leaves (sclerophylly), and adventitious roots with multi-layered velamen which allow them to quickly absorb any available water from rain or mist (Porembski \& Barthlott 1995). They are also adapted to fire (Alves 1994; Ibisch et al. 1995). The family has many representatives in the 'campo rupestre' vegetation (high-altitude rocky grasslands) of the Espinhaço Range, SE Brazil (Giulietti \& Pirani 1988). The region has a very high level of endemism, probably associated with altitudinal isolation (Alves \& Kolbek 1994).

In contrast with the great taxonomic interest in the family (Mello-Silva 2005), there are very few works focusing on the ecology or pollination biology of
Velloziaceae from the Espinhaço Range (Sazima \& Sazima 1990; Landau et al. 1998). Our objectives were to study the breeding system and pollinator behaviour of two sympatric species of Vellozia, V. leptopetala Goeth. \& Henr. and V. epidendroides Mart. ex Schult. $\&$ Schult., which differ in microhabitat preference and genetic diversity (Franceschinelli et al. 2006).

\section{Material and methods}

Study site - The study took place in 'campo rupestre' vegetation (19 $17^{\circ} \mathrm{S}, 43^{\circ} 35^{\prime} \mathrm{W}, \mathrm{ca} .1,200 \mathrm{~m}$ a.s.1.), at the southern portion of the Espinhaço Range, a quartzitic formation with mean and maximum altitudes of $1,000 \mathrm{~m}$ and $2,000 \mathrm{~m}$ respectively, and N-S orientation. The region is characterized by a Köppen type Cwb climate (mesothermic), with a wet summer season and mean annual rainfall of $1,500 \mathrm{~mm}$ concentrated during November-March (Nimer 1989). The vegetation is composed of savanna-like communities and gallery forests at lower altitudes, and campo rupestre vegetation beginning at approximately 1,000 m (Giulietti et al. 1987).

Biological material - The flowers of both species are bisexual, regular and solitary, and have a petaloid perianth; the ovary is inferior, with three locules and ovules on stalked placentas; the style is slender and ends in a dry, capitate stigma. The 18 anthers are bright yellow, pollen is abundant and shed in tetrads (Smith $\&$ Ayensu 1976). Anthesis is diurnal, and flowers remain receptive for two to three days (Sazima \& Sazima 1990; Oliveira et al. 1991). Fruits are dry, hard capsules. Seeds are tiny (1.1-1.5 mm diam) and spheroid, and show no particular mechanism for dispersal, although it has been suggested they are wind-dispersed (Ibisch et al. 2001). Populations of both species occur throughout Serra do Cipó, and V. epidendroides extends $200 \mathrm{~km}$ further north.

Vellozia leptopetala individuals grow exclusively on rocky outcrops in campos rupestres. Plants are woody in appearance, $0.5-1.5 \mathrm{~m}$ high. Populations are characterized by annual synchronous blooms that last less than a month, some weeks after the first spring rains. Flowers are large (3.4-4.0 cm diam), white, with six narrow and patent tepals that turn reflexive and with lilac shades after the first day (Fig. 1A). According to Sazima and Sazima (1990), these modifications, together with the tube-like arrangement of the purple filaments, denote evolved adaptations for hummingbird pollination in this otherwise melittophilous genus. 
Vellozia epidendroides individuals are short with a slender pseudostem (30-40 $\mathrm{cm}$ high), and grow in well-defined patches over extensive areas in open stony grasslands (Fig. 1B). Each ramet bears a solitary large (3.5-4.2 $\mathrm{cm}$ diam) white flower, with six broad tepals suberect at anthesis. The flowering period is less concentrated than that of $V$. leptopetala, and different patches of the species bloom from late summer (March) throughout May.

Methods - Individual flowers were manipulated to test the level of self-compatibility as well as the need for pollinating agents, on 50 plants of each species. Four pollination treatments were performed: 1) hand crosspollination, by emasculation, followed by pollinating each flower with pollen from two plants distant at least $100 \mathrm{~m}$ from the recipient ( $\mathrm{n}=40$ flowers on 30 plants), 2) hand self-pollination, by pollinating a flower with its own pollen ( $\mathrm{n}=40$ on 20 plants), 3) agamospermy, by emasculation ( $\mathrm{n}=20$ flowers on 20 plants), and 4) spontaneous self-pollination, in which buds were bagged and left to pollinate spontaneously ( $\mathrm{n}=40$ for $V$. epidendroides and 60 for $V$. leptopetala, on 20 plants). Each treatment flower was bagged with finemesh (ca. $0.3 \mathrm{~mm}$ width) nylon net until the fruit was fully developed. In addition, 40 unmanipulated flowers from 30 plants were bagged after the stigma ceased to be receptive and used as control, open-pollinated flowers. Twenty-five pre-anthesis flowers of each species were bagged to measure daily nectar volume and sugar concentration. To calculate pollen-ovule $(\mathrm{P} / \mathrm{O})$ ratios, pollen grains from one anther and ovules from one locule of three different flowers were counted with the aid of gridded slides.

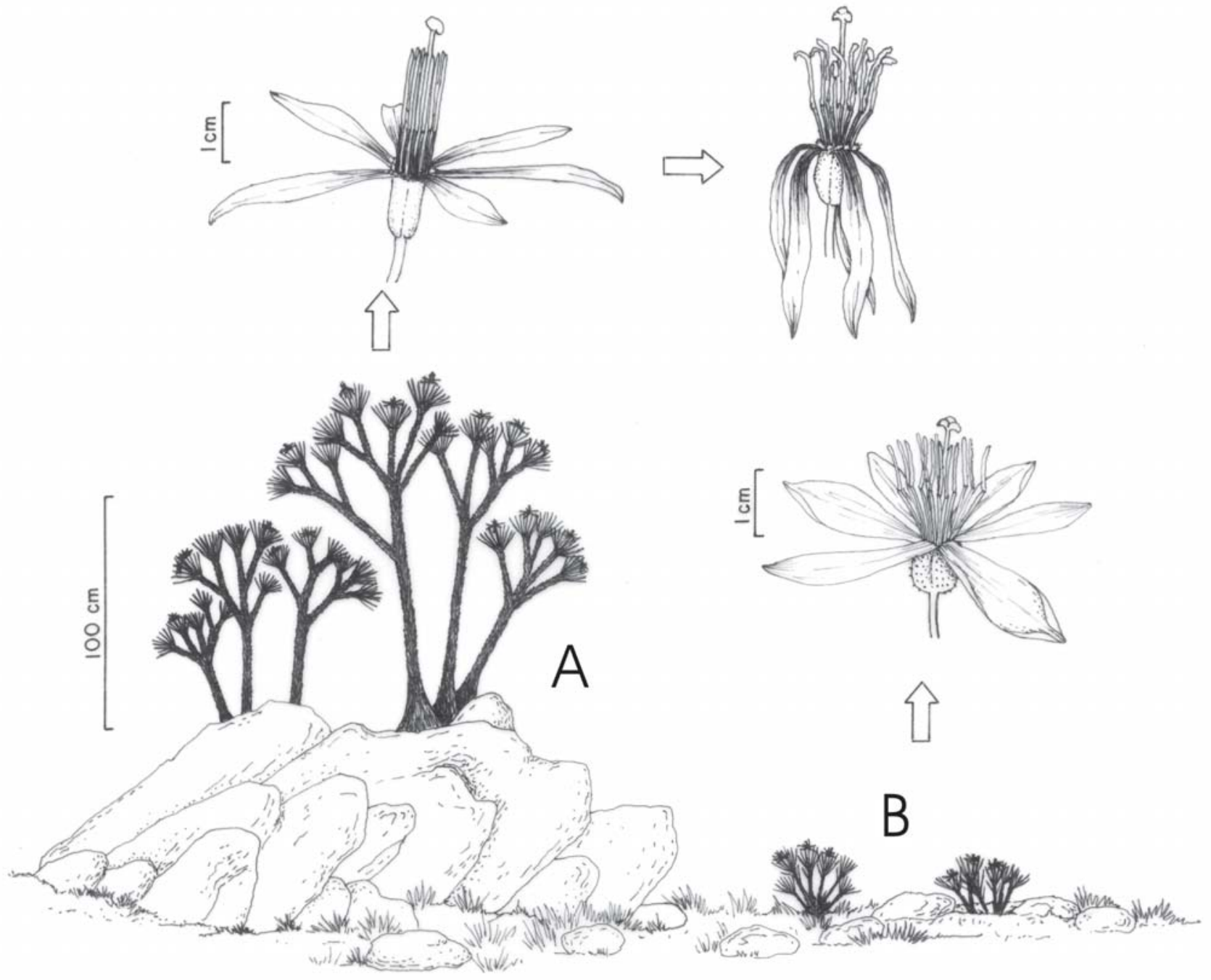

Figure 1. Habit and flower morphology. A) Vellozia leptopetala, growing on rocky outcrops (detail shows changes from first- to secondday flower), B) V. epidendroides, growing on pebbly ground, Serra do Cipó, MG. 
After maturation, we collected the fruits and recorded the number of seed per fruit. Few marked flowers were lost or damaged throughout fruit development. To calculate mean seed number, however, we excluded seedless fruits. Welch's approximate $t$ statistic was used to check for difference in seed set among treatments (Zar 1996). Two indices associated with the mating system were calculated, following Lloyd and Schoen (1992): the selfcompatibility index (SCI), which is the ratio of hand self-pollination to hand cross-pollination seed set, and the self-fertility index (SFI), which is the ratio of spontaneous to hand cross-pollination seed set. Voucher specimens were deposited in the BHCB Herbarium (Botany Department, Federal University of Minas Gerais, Brazil).

Floral visitor activity was recorded during 240 hours of field observations, usually from 0600 to $1800 \mathrm{~h}$ (early morning until sunset, approximately) during the flowering season of each species. The approach, resource gathering and movements regarding contact with stigma were recorded for all visitors. Hummingbirds were photographed and identified by comparison with collection specimens. Insects were captured with an entomological net, mounted and identified, and deposited in the first author's insect collection.

\section{Results}

Reproductive biology and floral features - The large patches of $V$. epidendroides bearing hundreds of white flowers with bright yellow anthers are very conspicuous in the rupestrian landscape. Although large individuals of $V$. leptopetala can reach 200 flowers, the floral display is less striking because tepals are slender, they bend down and acquire darkish hues in second-day flowers. Tepals of both species wither and darken after three to four days, and remain attached throughout fruit development or they are readily removed by florivores. Anthesis in both species starts in the early morning, and flowers are odorless. Anther dehiscence is longitudinal, synchronous, and may occur from one hour before anthesis to 2-3 hours after tepals are fully displayed. Deposition of self-pollen on the stigma before tepals spread is common. Nectar in V. leptopetala is produced in the hypanthium, in small volumes (5.22 \pm $1.45 \mu \mathrm{l} / 24 \mathrm{~h}, \mathrm{n}=25)$ and low sugar concentration (11.62 $\pm 3.31 \%, \mathrm{n}=25$ ), but no measurable quantities of nectar were extracted from the other species. In both species, the number of pollen grains (about 777,600) divided by the number of ovules (900-1300) per flower corresponds to facultative xenogamy on Cruden's (1977) classification.

The results of the pollination treatments are shown in Table 1. Seedless capsules (fruits do not abscise) were abundant in both species except for control and cross-pollinated flowers. Vellozia epidendroides produced only $23 \%$ of fruits with few selfed-seeds when manually pollinated. This contrasted with the small number of seedless fruits $(7.5 \%)$ and the mean number of seeds per fruit $(194.4 \pm 148.0, n=37)$ derived from cross-pollination. No seeds resulted from either agamospermy or spontaneous pollination. Crosspollination seed set was significantly larger than control $(\mathrm{df}=40, \mathrm{p}<0.0001)$ and self-pollination $(\mathrm{df}=43$, $\mathrm{p}<0.0001$ ), and no significant difference was found between control and self-pollination seed set $(\mathrm{df}=14$, $\mathrm{p}=0.34$ ). Vellozia leptopetala, on the other hand, produced more fruits with selfed-seeds, both from spontaneously pollinated (40\%) and hand-pollinated flowers (28\%). As with V. epidendroides, no seeds resulted from agamospermy. There was a significant difference in mean seed set only between crosspollinated fruits $(484.5 \pm 318.0, \mathrm{n}=35)$ and all other treatments. There was no statistical difference between the number of control and selfed-seeds $(\mathrm{df}=15, \mathrm{p}=0.15)$. Although autogamous fruits produced a small number of seeds, self-incompatibility and the need for pollinators was confirmed for both species by means of the indices SCI and SFI, whose values were lower than an established cut-off point of $20 \%$.

Floral visitors - Both species were visited by a diversity of insects, of which only bees were effective pollinators. During peak hours (1000-1300 h) flowers received $9.8 \pm 9.4$ visits per hour. Medium and large bees predominated over social and small bees with respect to species number but not to relative abundance (Table 2). All bee visitors collected exclusively pollen.

The foraging strategy of bees depended on their size. In general, large bees (Megachilidae and most Apidae) landed either on the stigma, anthers, or even tepals, and usually touched both stigma and anthers with the hind legs and ventral part of abdomen and thorax in their search for pollen. They foraged from early morning until approximately $1600 \mathrm{~h}$. Small bees (Halictini, Ceratinini, and Trigonini) landed directly on the anthers and seldom touched the stigma while collecting pollen or when flying away. They 
Table 1. Seeds produced by different pollination treatments in Vellozia epidendroides and V. leptopetala (Velloziaceae), Serra do Cipó, MG. $\mathrm{n} / \mathrm{N}=$ number of fruits with seeds / number of flowers treated. The ratios of self to cross (SCI) and of spontaneous to cross-pollinated fruits (SFI) were calculated based on the mean seed number of fruits with seeds only.

\begin{tabular}{|c|c|c|c|c|c|c|}
\hline \multirow[b]{2}{*}{ Treatments } & \multicolumn{3}{|c|}{ V. epidendroides } & \multicolumn{3}{|c|}{ V. leptopetala } \\
\hline & mean $\pm \mathrm{SD}$ & (min-max) & $\mathrm{n} / \mathrm{N}$ & mean \pm SD & $(\min -\max )$ & $\mathrm{n} / \mathrm{N}$ \\
\hline Agamospermy & 0 & & $0 / 20$ & 0 & & $0 / 20$ \\
\hline $\begin{array}{l}\text { Self-pollination } \\
\text { manual }\end{array}$ & $31.2 \pm 28.0$ & $(3-92)$ & $9 / 40$ & $42.3 \pm 40.4$ & $(11-119)$ & $11 / 40$ \\
\hline spontaneous & 0 & & $0 / 40$ & $37.9 \pm 42.6$ & $(7-200)$ & $24 / 60$ \\
\hline Cross-pollination & $194.4 \pm 148.0$ & $(18-622)$ & $37 / 40$ & $484.5 \pm 318.0$ & $(11-1250)$ & $35 / 40$ \\
\hline Control & $35.9 \pm 33.1$ & $(3-122)$ & $34 / 40$ & $59.6 \pm 45.8$ & $(6-130)$ & $28 / 40$ \\
\hline SCI & 0.16 & & & 0.09 & & \\
\hline SFI & 0 & & & 0.08 & & \\
\hline
\end{tabular}

concentrated their visits between 0700 and $1000 \mathrm{~h}$, and were rarely seen after $1400 \mathrm{~h}$. The two species of Dialictus, as well as small social Apidae such as Ceratina sp., Trigona spinipes, Geotrigona subterranea, Paratrigona lineata and $P$. subnuda, were classified as thieves of both Vellozia, because their size allows them to reach and scrape the anthers without touching the stigma (which they did very rarely). All other bees were considered legitimate pollinators.

Six bees were common to both species (Table 2). Of these, Apis mellifera, Megachile (Chrysosarus) sp., and Paroxystoglossa sp. were the most frequent. Apis mellifera individuals remained for several minutes foraging on a single flower, and agonistic encounters with other species were common. They remained for most time in a single plant, compared to other visitors, which restricted their visits to less than a minute per flower and foraged on fewer flowers per plant. Vellozia epidendroides was visited by 16 bee species, with different importance as pollinators (Table 2). Megachile (Chrysosarus) and A. mellifera were the most common. Augochlorini were frequent in the morning, whereas most Apidae were more common in the afternoon. Visits by large and medium bees such as Diadasiana riparia, Melipona quinquefasciata, Xylocopa spp., Tetrapedia sp. 1, and Centris sp. were uncommon, but they always touched the stigma while foraging. Vellozia leptopetala attracted fewer bee species, three of which were frequent pollinators, three infrequent, and three occasional (Table 2). The most common bees were Paroxystoglossa sp. and Dialictus sp. 1. Most bees initiated their visits around $0700 \mathrm{~h}$ and reduced their visits in the afternoon, although Dialictus, Megachile (Chrysosarus), Trigona spinipes, Ceratina and A. mellifera were still active until approximately $1700 \mathrm{~h}$. This species was intensively visited by Augastes scutatus (Temminck), a territorial hummingbird, which foraged from dawn till dusk. Hummingbirds visited $50-100 \%$ of the flowers in each plant, including second-day flowers, which were less visited by bees. Although they concentrated their visits on V. leptopetala, hummingbirds visited other nearby flowering species such as Vellozia declinans, Cuphea sp. and Vochysia sp. during the same foraging bout.

\section{Discussion}

Seed set in harsh environments may be affected by reduced resources, and the rupestrian flora is known to be subjected to different levels of climatic and edaphic stress (Alves \& Kolbek 1994; Fernandes et al. 1996; Scatena \& Moraes 1996; Jacobi et al. 2000). Vellozia species, however, are among the plants best adapted to these environments (Gaff 1987; Alves \& Kolbek 1994; Porembski \& Barthlott 2000), through drought-resistance structures, mechanisms which allow for quick uptake of water and mist, and by synchronizing flower production with rainfall. It is therefore likely that seed production in $V$. epidendroides and $V$. leptopetala is primarily pollenlimited due to the combination of several mechanisms that promote wrong pollen deposition and an inadequate number of legitimate visits, as discussed below.

The few works available on the breeding system of Vellozia had already pointed out that several species are self-incompatible (Oliveira et al. 1991; M. Sazima unpubl. data). These studies, however, did not contemplate a quantitative survey of seeds. Here we confirmed self-sterility in both species with basis on 
Table 2. Bee visitors of Vellozia leptopetala and V. epidendroides, Serra do Cipó, MG. Pf = frequent pollinator, Pi = infrequent pollinator, $\mathrm{Oc}=$ thief, but occasional pollinator, $\mathrm{Th}=$ thief.

\begin{tabular}{|c|c|c|c|}
\hline Family/Tribe & Species & V. leptopetala & V. epidendroides \\
\hline \multicolumn{4}{|l|}{ HALICTIDAE } \\
\hline \multirow[t]{4}{*}{ Augochlorini } & Augochloropsis cleopatra (Schrottky) & & Oc \\
\hline & Augochloropsis sp. & Oc & \\
\hline & Paroxystoglossa sp. & Oc & Oc \\
\hline & Pseudaugochlora graminea (Fabricius) & Oc & \\
\hline \multirow[t]{2}{*}{ Halictini } & Dialictus sp. 1 & Th & \\
\hline & Dialictus sp. 2 & Th & \\
\hline \multicolumn{4}{|c|}{ MEGACHILIDAE } \\
\hline \multirow[t]{2}{*}{ Megachilini } & Megachile (Chrysosarus) sp. & $\mathrm{Pf}$ & $\mathrm{Pf}$ \\
\hline & Megachile (Pseudocentron) sp. & Pf & Pf \\
\hline \multicolumn{4}{|l|}{ APIDAE } \\
\hline Apini & Apis mellifera $\mathrm{L}$. & Pf & Pf \\
\hline Ceratinini & Ceratina (Ceratinula) sp. & Th & \\
\hline \multirow[t]{2}{*}{ Centridini } & Centris (Hemisiella) sp. & $\mathrm{Pi}$ & \\
\hline & Centris sp. & & $\mathrm{Pi}$ \\
\hline Emphorini & Diadasina riparia (Ducke) & & $\mathrm{Pi}$ \\
\hline Meliponini & Melipona quinquefasciata Lepeletier & & $\mathrm{Pi}$ \\
\hline \multirow[t]{2}{*}{ Tetrapediini } & Tetrapedia sp. 1 & & $\mathrm{Pi}$ \\
\hline & Tetrapedia sp. 2 & $\mathrm{Pi}$ & \\
\hline \multirow[t]{4}{*}{ Trigonini } & Geotrigona subterranea (Friese) & & Th \\
\hline & Paratrigona lineata (Lepeletier) & & Th \\
\hline & Paratrigona subnuda Moure & & Th \\
\hline & Trigona spinipes (Fabricius) & Th & Th \\
\hline \multirow[t]{3}{*}{ Xylocopini } & Xylocopa truxali Hurd \& Moure & & $\mathrm{Pi}$ \\
\hline & Xylocopa (Neoxylocopa) sp. & $\mathrm{Pi}$ & $\mathrm{Pi}$ \\
\hline & Xylocopa (Schonnherria) sp. & & $\mathrm{Pi}$ \\
\hline Total species & & 13 & 16 \\
\hline
\end{tabular}

the number of seeds per fruit, and provide evidence for facultative xenogamy based on their $\mathrm{P} / \mathrm{O}$ ratios. Dispersal of pollen grains in tetrads and pollinator efficiency probably contribute to a lower $\mathrm{P} / \mathrm{O}$ ratio than that expected with basis only on the degree of selfincompatibility (Cruden \& Miller-Ward 1981). Seed set occurred in a few fruits produced by spontaneous (only in V. leptopetala) and manual self-pollination. A similar pattern for V. squamata, a "cerrado" (Brazilian savanna) species was proposed by Oliveira et al. (1991) to be a post-fertilization rejection mechanism, included broadly in the late-acting self-incompatibility category. Overall, ovarian and other late-acting selfincompatibility systems are still under investigation (Oliveira et al. 1991), and this validates efforts to examine the causes and effects of self-pollination.

Different mechanisms of self-pollen transfer were identified in both Vellozia. One is anther dehiscence prior to flower opening. At this time the style is in touch with the anthers, and self-pollen is deposited on the stigma. Not all flowers, however, opened their anthers before anthesis, so a proportionally more important mechanism promoting self-pollination is geitonogamy. Vellozia leptopetala, in particular, has a massive floral display, which leads bees and hummingbirds to visit many flowers in each plant. A long sequence of visits within a plant results in a high percentage of geitonogamous pollination (Robertson 1992; Robertson \& MacNair 1995; Ohashi \& Yahara 2002), detrimental in both species given their high level of selfincompatibility. Finally, given that there is no specific mechanism for seed dispersal and this is probably limited to a few meters from the mother plant, it is also possible that a considerable percentage of outgoing pollen is transferred among genetically related plants in the neighborhood, and contributes to inbreeding depression resulting in low seed set.

Wrong-pollen delivery by heterospecific pollen transfer is equally detrimental for seed set, but probably less frequent, and occurs mainly in V. leptopetala. The promiscuous behavior of hummingbirds, which visit more than one plant species while foraging, could result 
in heterospecific pollen loads and stigma clogging. No foreign pollen was present in the bees captured, so hummingbirds appear to be the only pollinators involved in significant improper pollen transfer. Sazima and Sazima (1990) reported lack of bees visiting $V$. leptopetala in a nearby area of comparable altitude, and attributed this to trends towards ornithophily represented by changes in floral morphology and color, together with dilute nectar. In agreement with their conclusions, and although we recorded several bee species in $V$. leptopetala, visits were mostly to firstday flowers, and individuals collected exclusively pollen. The changes in color and tepal display suffered by second-day flowers, and possibly aided by pollen depletion, makes this species less attractive to bees and comparatively more visited by hummingbirds.

In spite of a high frequency of visits, it is possible that the system is pollinator-limited because of two reasons. First, large floral displays are known to attract more visitors but the number of visits per individual flower may be proportionally reduced (Robertson 1992; Iwasa et al. 1995; Robertson \& MacNair 1995; Larson \& Barrett 2000; Ohashi \& Yahara 2002). Second, in both species the amount of pollen removed without effective pollen delivery was substantial, because visits from legitimate pollinators, represented by large and medium bees, were rare with few exceptions. In addition, theft was common, performed by several small bees and also by A. mellifera. This bee, even if a legitimate pollinator, is an expensive one, because it removes large amounts of pollen of which only a small portion is deposited on stigmas. Because it is a social species, the proportion of visits was high compared to solitary bees.

Although the plants studied share several life history characters and most of the mechanisms promoting pollen limitation, the intensity of some of these was different, and were used to help explain differences in genetic variability between V. leptopetala and V. epidendroides found in a research performed on the same populations of this study (Franceschinelli et al. 2006). Overall, V. leptopetala showed high inbreeding within isolated patches and lower genetic diversity than $V$. epidendroides. The former, which grows exclusively on outcrops and is therefore more subjected to genetic isolation and geitonogamy, has a territorial hummingbird as one of the main pollinators. This territorial behavior would restrict pollen spread to nearby plants, adding to the negative effects of limited seed dispersal, as discussed above. Vellozia epidendroides, which relies only on bees for pollination, could retain genetic diversity by means of a larger, less synchronized and less isolated floral display. Finally, the clonal growth of both species may explain the maintenance of high levels of selfincompatibility, which is known to decline in association with abiotic factors that reduce the efficacy of pollinators, such as altitude, isolation, and xeric or exposed environments (Levri 1998).

\section{Acknowledgments}

We thank G.W. Fernandes, for granting access to the research area, F. Silveira and members of his laboratory for their help with bee identification, Myrian M. Duarte for the drawings, and Andrea C. Barbosa for invaluable field assistance. P. Kevan's comments greatly improved a previous version of the manuscript. The comments of two anonymous reviewers were also very helpful. The director and staff of Serra do Cipó National Park provided logistic support. This research was supported by FAPEMIG (CRA 1590/98).

\section{References}

Alves, R.J.V. 1994. Morphological age determination and longevity in some Vellozia populations in Brazil. Folia Geobotanica et Phytotaxonomica 29: 55-59.

Alves, R.J.V. \& Kolbek, J. 1994. Plant species endemism in savanna vegetation on table mountains (Campo Rupestre) in Brazil. Vegetatio 113: 125-139.

Ashman, T.L.; Knight, T.M.; Steets, J.A.; Amarasekare, P.; Burd, M.; Campbell, D.R.; Dudash, M.R.; Johnston, M.O.; Mazer, S.J.; Mitchell, R.J.; Morgan, M.T. \& Wilson, G.W. 2004. Pollen limitation of plant reproduction: ecological and evolutionary causes and consequences. Ecology 85: 2408-2421.

Brown, B.J. \& Mitchell, R.J. 2001. Competition for pollination: effects of pollen of an invasive plant on seed set of a native congener. Oecologia 126: 43-49.

Collevatti, R.G.; Amaral, M.E. \& Lopes, F.S. 1997. Role of pollinators in seed set and a test of pollen limitation hypothesis in the tropical weed Triumfetta semitriloba (Tiliaceae). Revista de Biologia Tropical 45: 1401-1407.

Cruden, R.W. 1977. Pollen-ovule ratios: a conservative indicator of breeding systems in flowering plants. Evolution 31: 32-46.

Cruden, R.W. \& Miller-Ward, S. 1981. Pollen-ovule ratio, pollen size, and the ratio of stigmatic area to the pollenbearing area of the pollinator: an hypothesis. Evolution 35: 964-974.

de Jong, T.J.; Waser, N.M. \& Klinkhamer, P.G.L. 1993. Geitonogamy: the neglected side of selfing. Trends in Ecology and Evolution 8: 321-325. 
Feldman, T.S.; Morris, W.F. \& Wilson, G.W. 2004. When can two plant species facilitate each other's pollination? Oikos 105: 197-207.

Fernandes, G.W.; Carneiro, M.A.A.; Lara, A.C.F.; Allain, L.R.; Andrade, G.I.; Julião, G.R.; Reis, T.R. \& Silva, I.M. 1996. Galling insects on neotropical species of Baccharis (Asteraceae). Tropical Zoology 9: 315-332.

Fishman, L. \& Wyatt, R. 1999. Pollinator-mediated competition, reproductive character displacement, and the evolution of selfing in Arenaria uniflora (Caryophyllaceae). Evolution 53: 1723-1733.

Franceschinelli, E.V.; Jacobi, C.M.; Drummond, M.G. \& Resende, M.F.S. 2006. The genetic diversity of two Brazilian Vellozia (Velloziaceae) with different patterns of spatial distribution and pollination biology. Annals of Botany 97: 585-592.

Gaff, D.F. 1987. Desiccation tolerant plants in South America. Oecologia 74: 133-136.

Giulietti, A.M.; Menezes, N.L.; Pirani, J.R.; Meguro, M. \& Wanderley, M.G. 1987. Flora da Serra do Cipó, Minas Gerais: Caracterização e lista das espécies. Boletim de Botânica da Universidade de São Paulo 9: 1-152.

Giulietti, A.M. \& Pirani, J.R. 1988. Patterns of geographic distribution of some plant species from Espinhaço Range, Minas Gerais and Bahia, Brazil. Pp. 39-69. In: P.E. Vanzolini \& W.R. Heyer (eds.). Proceedings of a Workshop on Neotropical Distribution Patterns. Rio de Janeiro, Academia Brasileira de Ciências.

Guitián, J. \& Navarro, L. 1996. Allocation of reproductive resources within inflorescences of Petrocoptis grandiflora (Caryophyllaceae). Canadian Journal of Botany 74: 1482-1486.

Haig, D. \& Westoby, M. 1988. On limits to seed production. American Naturalist 131: 757-759.

Ibisch, P.L.; Rauer, G.; Rudolph, D. \& Barthlott, W. 1995. Floristic, biogeographical and vegetational aspects of Precambrian rock outcrops (inselbergs) in Eastern Bolivia. Flora 190: 299-314.

Ibisch, P.L.; Nowicki, C.; Vasquez, R. \& Koch, K. 2001. Taxonomy and biology of Andean Velloziaceae: Vellozia andina sp. nov. and notes on Barbaceniopsis (including Barbaceniopsis castillonii comb. nov.). Systematic Botany 26: 5-16.

Iwasa, Y.; de Jong, T.J. \& Klinkhamer, P.G.L. 1995. Why pollinators visit only a fraction of the open flowers on a plant: the plant's point of view. Journal of Evolutionary Biology 8: 439-453.

Jacobi, C.M.; Carmo, R.M. \& Oliveira, R.S. 2000. The reproductive biology of two species of Diplusodon Pohl (Lythraceae) from Serra do Cipó, southeastern Brazil. Plant Biology 2: 670-676.

Landau, E.C.; Gonçalves-Alvim, S.J.; Fagundes, M. \& Fernandes, G.W. 1998. Riqueza e abundância de herbívoros em flores de Vellozia nivea (Velloziaceae). Acta Botanica Brasilica 12: 403-409.

Larson, B.M.H. \& Barrett, S.C.H. 2000. A comparative analysis of pollen limitation in flowering plants. Biological Journal of the Linnean Society 69: 503-520.
Larson, K.C.; Fowler, S.P. \& Walker, J.C. 2002. Lack of pollinators limits fruit set in the exotic Lonicera japonica. American Midland Naturalist 148: 54-60.

Levri, M.A. 1998. The effect of timing of pollination on the mating system and fitness of Kalmia latifolia (Ericaceae). American Journal of Botany 85: 1626-1630.

Lindell, T. 1998. Breeding systems and crossing experiments in Anemone patens and in the Anemone pulsatilla group (Ranunculaceae). Nordic Journal of Botany 18: 549-561.

Lloyd, D.G. \& Schoen, D.J. 1992. Self- and cross-fertilization in plants. I. Functional dimensions. International Journal of Plant Sciences 153: 358-369.

Mello-Silva, R. 2005. Morphological analysis, phylogenies and classification in Velloziaceae. Botanical Journal of the Linnean Society 148: 157-173.

Montgomery, B.R.; Kelly, D.; Robertson, A.W. \& Ladley, J.J. 2003. Pollinator behaviour, not increased resources, boosts seed set on forest edges in a New Zealand Loranthaceous mistletoe. New Zealand Journal of Botany 41: 277-286.

Moody-Weiss, J.M. \& Heywood, J.S. 2001. Pollination limitation to reproductive success in the Missouri evening primrose, Oenothera macrocarpa (Onagraceae). American Journal of Botany 88: 1615-1622.

Niesenbaum, R.A. 1999. The effect of pollen load size and donor diversity on pollen performance, selective abortion, and progeny vigor in Mirabilis jalapa (Nyctaginaceae). American Journal of Botany 86: 261-268.

Nimer, E. 1989. Climatologia do Brasil. Rio de Janeiro, Instituto Brasileiro de Geografia e Estatística.

Ohara, M. \& Higashi, S. 1994. Effects of inflorescence size on visits from pollinators and seed set of Corydalis ambigua (Papaveraceae). Oecologia 98: 25-30.

Ohashi, K. \& Yahara, T. 2002. Visit larger displays but probe proportionately fewer flowers: counterintuitive behaviour of nectar-collecting bumble bees achieves an ideal free distribution. Functional Ecology 16: 492-503.

Oliveira, P.E.; Gibbs, P.E. \& Bianchi, M. 1991. Pollination and breeding system of Vellozia squamata (Liliales, Velloziaceae) - a species of the Brazilian cerrados. Botanica Acta 104: 392-398.

Owoseye, J.A. \& Sanford, W.W. 1972. Ecological study of Vellozia schnitzleinia, a drought-enduring plant of Northern Nigeria. Journal of Ecology 60: 807-817.

Porembski, S. \& Barthlott, W. 1995. On the occurrence of a velamen radicum in Cyperaceae and Velloziaceae. Nordic Journal of Botany 15: 625-629.

Porembski, S. \& Barthlott, W. 2000. Granitic and gneissic outcrops (inselbergs) as centers of diversity for desiccation-tolerant vascular plants. Plant Ecology 151: 19-28.

Queller, D.C. 1985. Proximate and ultimate causes of low fruit production in Asclepias exaltata. Oikos 44: 373-381. 
Robertson, A.W. 1992. The relationship between floral display size, pollen carryover and geitonogamy in Myosotis colensoi (Kirk) MacBride (Boraginaceae). Biological Journal of the Linnean Society 46: 333-349.

Robertson, A.W. \& MacNair, M.R. 1995. The effects of floral display on pollinator service to individual flowers of Myosotis and Mimulus. Oikos 72: 106-114.

Sazima, M. \& Sazima, I. 1990. Hummingbird pollination in two species of Vellozia (Liliiflorae, Velloziaceae) in Southeastern Brazil. Botanica Acta 103: 83-86.

Scatena, V.L. \& de Moraes, A.R.S. 1996. Roots, leaves and scapes anatomy of species of Paepalanthus subgenus Platycaulon (Eriocaulaceae). Arquivos de Biologia e Tecnologia 39: 1021-1035.
Schiller, J.R.; Zedler, P.H. \& Black, C.H. 2000. The effect of density-dependent insect visits, flowering phenology, and plant size on seed set of the endangered vernal pool plant Pogogyne abramsii (Lamiaceae) in natural compared to created vernal pools. Wetlands 20: 386-396.

Shibayama, Y \& Kadono, Y. 2003. Floral morph composition and pollen limitation in the seed set of Nymphoides indica populations. Ecological Research 18: 725-737.

Smith, L.B. \& Ayensu, E.S. 1976. A revision of American Velloziaceae. Smithsonian Contribution Botany 30: 1-172.

Yang, C.F.; Sun, S.G. \& Guo, Y.H. 2005. Resource limitation and pollen source (self and outcross) affecting seed production in two louseworts, Pedicularis siphonantha and P. longiflora (Orobanchaceae). Botanical Journal of the Linnean Society 147: 83-89.

Zar, J.H. 1996. Biostatistical Analysis. Prentice Hall, Englewood Cliffs, UK. 